\title{
Kinesiology Taping reduces lymphedema of the upper extremity in women after breast cancer treatment: a pilot study
}

\author{
Iwona Malicka, Agnieszka Rosseger, Justyna Hanuszkiewicz, Marek Woźniewski
}

Wydział Fizjoterapii, Akademia Wychowania Fizycznego we Wrocławiu

\begin{abstract}
Introduction: Secondary lymphedema affects approximately $40 \%$ of women treated for breast cancer and is recognized as a major problem associated with the therapy of malignant tumors. Consequently, new therapeutic methods are constantly being sought to effectively eliminate the condition. One of the new forms of edema management, especially in the initial stages of edematous development, is Kinesiology Taping (KT).

Aim of the study: The aim of the study was to assess the effects of KT applications on the extent of lymphedema of the upper extremity in women post cancer treatment.

Material and methods: The study group consisted of 28 women after axillary lymphadenectomy due to breast cancer. All the patients were diagnosed with grade I secondary lymphedema. Kinesiology Taping was applied to a total of 14 randomly selected women. The remaining 14 patients constituted a control group. The extent of lymphedema was measured using a centimeter tape and Limb Volumes Professional 5.0 software.

Results: A significant reduction in the extent of lymphedema $(p=0.0009)$ was achieved in the KT group between baseline and post-treatment assessments. No such reduction, however, was found in the control group $(p=0.36)$.

Conclusions: Kinesiology Taping applications are an effective method of early-stage edema management. Kinesiology Taping may be a safe new therapeutic option in patients who are contraindicated for the use of other methods.
\end{abstract}

Key words: breast cancer, lymphedema, Kinesiology Taping.

\section{Introduction}

Studies conducted to date show that the most effective method of secondary lymphedema treatment in women after axillary lymphadenectomy due to breast cancer is complete decongestive therapy (CDT) consisting of manual lymphatic drainage (MLD), compression techniques (bandaging, compression sleeves), physical exercise and skin care. Complete decongestive therapy makes it possible to achieve an average of $45 \%$ of edema reduction. A slightly less effective therapeutic option is complex physical therapy (CPT), a combination of different methods of lymphedema treatment, typically MLD and intermittent pneumatic compression (IPC), though other options are also possible depending on the healthcare facility's experience. With CPT, edema can be relieved by an average of ca. 30\%. Self-application of MLD or IPC allows for up to $25 \%$ edema reduction. The efficacy of other methods used for the treatment of secondary lymphedema of the upper extremity, such as continuous compression therapy, laser therapy, self-massage, physical exercise or appropriate extremity positioning, ranges between $5 \%$ and $11 \%$ of edema reduction [1].
Analyses of therapeutic efficacy of different secondary lymphedema-reducing methods performed so far fail to include Kinesiology Taping (KT) because it is a relatively new treatment modality, though it becomes increasingly common for lymphedema control. The mechanism underlying KT has not, as yet, been fully understood. Similarly to other methods that deform the skin of the extremity, KT increases lymph flow and can be used in the treatment of peripheral lymphedema. According to authors using KT in their practice, the method relieves tissue fluid congestion, augments blood and lymph circulation, and improves subcutaneous lymphatic drainage [2, 3]. Kinesiology Taping applications pull the skin slightly, creating more space between the dermis and fascia [4]. Lymphatic taping is thus quite similar to lymphatic drainage, though it allows patients to receive therapeutic benefits 24 hours a day [5]. Based on analysis of physiological effects it can also be argued that KT is more similar to compression therapy in that it reduces capillary filtration rather than enhancing lymphangiomotor function.

A few studies (e.g. Tsai et al.) [6] demonstrated no significant differences in edema reduction between 
standard CDT combined with pneumatic compression (bandage) and modified CDT (combined with KT). A $17 \%$ edema reduction was seen in the group treated with CFT combined with bandage and only $3 \%$ reduction in the group receiving CFT with KT. It was found, however, that KT might be a more useful option for patients with poor tolerance of bandaging, as it is more comfortable to the skin especially in hot climates and during the summer. Moreover, KT is a simpler and less demanding technique than compression bandaging, which prompts patients to use it more systematically. At the same time, the study demonstrated a higher risk of wounds caused by K-tape than bandage.

Kinesiology Taping, on the other hand, may have a significant influence on lymph flow during exercise, as noted in experimental studies in rabbits. Even though the use of tapes resulted in no significant differences in lymph flow, their application during passive exercise markedly increased lymph flow rates [7]. The observation can be explained by thermal and mechanical processes involved in KT.

In view of the above, the aim of the study was to assess the effects of KT on the extent of lymphedema of the upper extremity in women post cancer treatment.

\section{Material and methods}

\section{Study group}

The study was conducted in a group of 28 middleaged women, with a mean age of 59.75 years $( \pm 5.95)$, after axillary lymphadenectomy due to breast cancer. All the study patients were diagnosed with grade I secondary lymphedema and were not given any anti-edema treatment either before or during KT applications. The patients were randomized into 2 groups.
The first group (study group, $n=14$ ) consisted of women who received $\mathrm{KT}$ applications. $78.6 \%$ of them had undergone mastectomy and $21.4 \%$ - breast-conserving surgery. In addition, $71.4 \%$ had received radiotherapy, $85.7 \%$ - chemotherapy and $64.3 \%$ - hormone therapy. The mean post-treatment period was $6.0 \pm 4.8$ years.

Patients in the second group (control group, $n=14$ ) did not receive any anti-edema treatments. $85.7 \%$ of them had undergone mastectomy and $14.3 \%$ - breastconserving surgery. In addition, $35.7 \%$ of study participants had received adjuvant treatment in the form of radiotherapy, $71.4 \%$ - chemotherapy and 50\% - hormone therapy. The mean post-treatment period was $5.8 \pm 4.8$ years.

There were no significant differences between groups in variables that could potentially affect study results. Detailed characteristics of study patients are given in Table I.

\section{Methods}

\section{Lymphedema measurement}

All the women studied had the circumference of their upper extremities measured at 6 levels, using a centimeter tape. The first level was at the proximal base of the metacarpal bones and the second across the ulnar and radial styloid processes. The remaining four levels were defined by measuring consecutive $10 \mathrm{~cm}$ distances from the styloid processes up the extremity.

The results obtained from the above measurement, based on the difference of the circumference between the swollen limb and the not-swollen limb were used to calculate the edema volume [ml] (Table II). The Limb Volumes Professional 5.0 program was used to perform the calculations. This is a software for limb edema and lymphedema tracking, documentation and reporting.

Tab. I. Characteristics of study patients and significance of values for differences between the study group (1) and the control group (2)

\begin{tabular}{lccc}
\hline Parameter & Group $1, n=14$ & Group 2, $n=14$ & $p$ \\
\hline Age [years] & $60.1 \pm 6.3$ & $59.5 \pm 5.7$ & 0.56 \\
\hline Body mass $[\mathrm{kg}]$ & $75.4 \pm 12.8$ & $76.2 \pm 11.8$ & 0.69 \\
\hline Body height $[\mathrm{cm}]$ & $161.5 \pm 3.9$ & $159.9 \pm 7.1$ & 0.29 \\
\hline Radical surgery $[n]$ & 11 & 12 & 0.87 \\
\hline Surgery on the right breast $[n]$ & 7 & 8 & 0.76 \\
\hline Post-surgery period [years] & $6.0 \pm 4.8$ & 13 & 0.76 \\
\hline Adjunctive treatment $[n]$ & 14 & 5 & 0.76 \\
\hline Radiotherapy $[n]$ & 10 & 10 & 0.11 \\
\hline Chemotherapy $[n]$ & 12 & 7 & 0.53 \\
\hline Hormone therapy $[n]$ & 9 & 0.53 \\
\hline
\end{tabular}


Tab. II. Example circumference result calculation into volume values

\begin{tabular}{|c|c|c|c|c|c|}
\hline \multirow{2}{*}{$\begin{array}{l}\text { Centimetres } \\
\text { from wrist }\end{array}$} & \multicolumn{2}{|c|}{ Circumferences $(\mathrm{cm})$} & \multirow[t]{3}{*}{ Segment number } & \multicolumn{2}{|c|}{ Volume (ml) } \\
\hline & Right (affected) & Left (not affected) & & \multirow[t]{2}{*}{ Right } & \multirow[t]{2}{*}{ Lef } \\
\hline 0 & 17 & 17 & & & \\
\hline 10 & 24 & 21 & 1 & 338 & 288 \\
\hline 20 & 26.5 & 26 & 2 & 508 & 441 \\
\hline 30 & 28.5 & 26.5 & 3 & 602 & 549 \\
\hline 40 & 33.5 & 31.8 & 4 & 767 & 678 \\
\hline Edema & & & & & \\
\hline
\end{tabular}

It automatically uses the application of circumferencebased methods to determine the edema volume on the basis on the appropriate algorithm.

The first measurement (1) was performed at baseline, i.e. prior to the initiation of therapy. The second - after 2 weeks of KT applications and the final one (in the study and control groups) after the completion of $\mathrm{KT}$, i.e. 4 weeks.

\section{Kinesiology Taping applications}

All the study group women received KT therapy. A total of 4 applications were made, one in each consecutive week. The patients were randomly divided into two sub-groups of seven. Each sub-group was given two different types of applications according to the KT methodology. Lymphatic application was performed using tape with a $1 \mathrm{~cm}$ wide base and tails divided into four parts. The maximum tension of the tails was $15 \%$, after holding down the base of the tape during application. During the tape application procedure the patients were in the sitting and supine position, depending on the application given.

In the first sub-group, the tape was applied to the edematous upper extremity in individual fan shapes on the arm and forearm, and along anastomoses (Fig. 1A).

It is assumed that in big lymphatic vessels of trunk planes in certain places there occur links with collec- tors of neighboring territories. These are so called anastomoses - fusions. Lymphatic encumbrances for the given region of lymph confluence can in such a case be transported to adjoining areas with lymph nodes without morbid condition. In our research this was the lymph nodes' area based opposite armpit: armpit armpit anastomosis.

In the second sub-group, the tape was applied only to the upper extremity in a double fan shape within the arm and forearm (Fig. 1B).

None of the above groups took part in any other physiotherapeutic sessions during the research. Within the groups there were also no physical improvement exercises.

\section{Statistical analysis}

Statistical analysis was made with STATISTICA software using basic descriptive statistics and, due to the fact that the patient groups were small, non-parametric analyses of the significance of differences: for independent variables (between groups) - the Mann-Whitney $U$ test; for dependent variables (between measurements within groups) - the Wilcoxon test; and for the analysis of reduction in the extent of lymphedema the Friedman test.
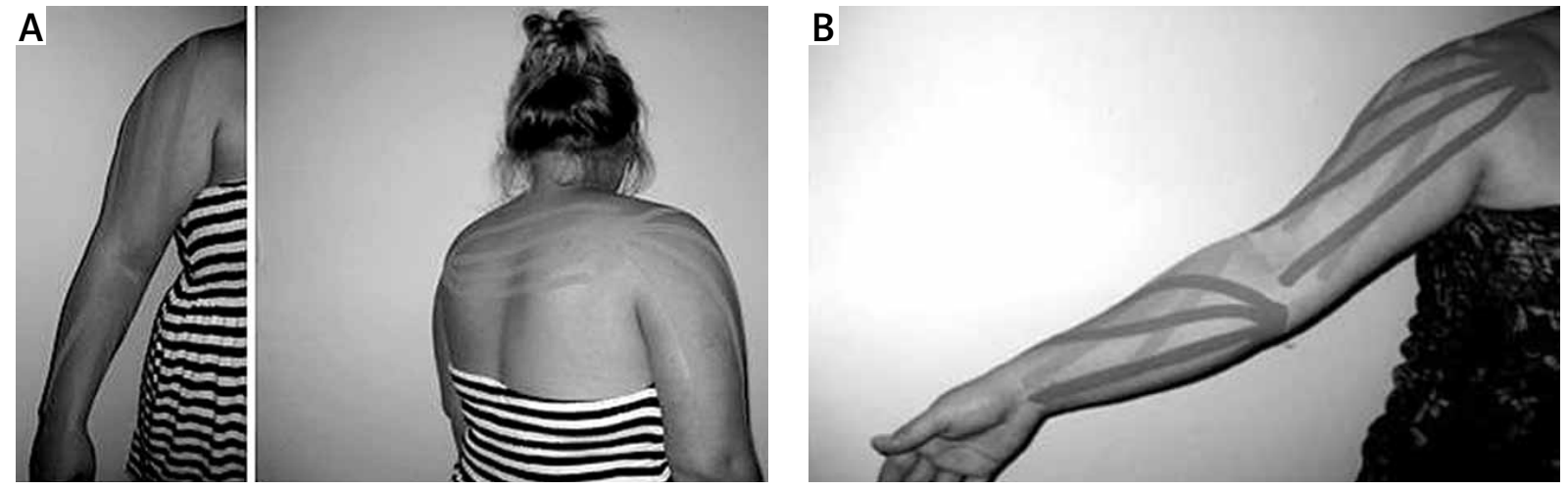

Fig. 1. A) KT applications in subgroup 1. B) KT applications in subgroup 2 
Tab. III. Significance of differences between edematous and the opposite extremity

\begin{tabular}{|c|c|c|c|c|c|c|}
\hline \multirow[t]{2}{*}{ Group } & \multicolumn{2}{|c|}{$\begin{array}{l}\text { Edematous extremity } \\
\qquad \mathrm{V}[\mathrm{ml}]\end{array}$} & \multicolumn{2}{|c|}{$\begin{array}{c}\text { Non-edematous extremity } \\
\qquad \mathrm{V}[\mathrm{ml}]\end{array}$} & \multirow{2}{*}{$\begin{array}{c}\text { Baseline } \\
\text { assessment } \\
p\end{array}$} & \multirow{2}{*}{$\begin{array}{c}\text { Final } \\
\text { assessment } \\
p\end{array}$} \\
\hline & $\begin{array}{c}\text { Baseline } \\
\text { assessment }\end{array}$ & $\begin{array}{l}\text { Final } \\
\text { assessment }\end{array}$ & $\begin{array}{c}\text { Baseline } \\
\text { assessment }\end{array}$ & $\begin{array}{l}\text { Final } \\
\text { assessment }\end{array}$ & & \\
\hline Study group (1) & $2511.43 \pm 532.26$ & $2275.51 \pm 482.12$ & $2230.78 \pm 353.61$ & $2230.78 \pm 353.61$ & 0.0005 & 0.47 \\
\hline Control group (2) & $2344.92 \pm 311.67$ & $2356.42 \pm 310.96$ & $2218.92 \pm 272.10$ & $2218.92 \pm 272.10$ & 0.02 & 0.02 \\
\hline
\end{tabular}

Tab. IV. Significance of differences between preliminary and final assessments within and between groups

\begin{tabular}{lccc}
\hline Group & \multicolumn{2}{c}{ Difference: edematous extremity vs. non-edematous extremity, $\mathrm{V}$ [ml] } \\
\cline { 2 - 4 } & Baseline assessment & Final assessment & $p$ \\
\hline Study group (1) & $280.35 \pm 231.89$ & $44.78 \pm 226.38$ & 0.0009 \\
\hline Control group (2) & $126.00 \pm 192.64$ & $137.50 \pm 192.74$ & 0.36 \\
\hline$p$ & 0.04 & 0.30 & $X$ \\
\hline
\end{tabular}

\section{Results}

The results were based on the total extremity values obtained from the circumference measurements with the use of LVP program.

During baseline assessment (1), a significant difference in total volume [ml] was found between the upper extremity on the operated side and the opposite side for both groups. Nonetheless, the difference was not demonstrated in the study group during final assessment (3) (cf. Table III). This means that in the group of patients undergoing KT applications a significant reduction in the extent of lymphedema was obtained between the baseline assessment -1 and final assessment - 3 (0.0009). No such difference was found in the control group (0.36), even though the study group (subjected to KT applications) had a statistically greater ( $p=0.04$ ) extent of lymphedema (cf. Table IV).

Further statistical analysis was performed only for the study group, describing in detail all changes ob-

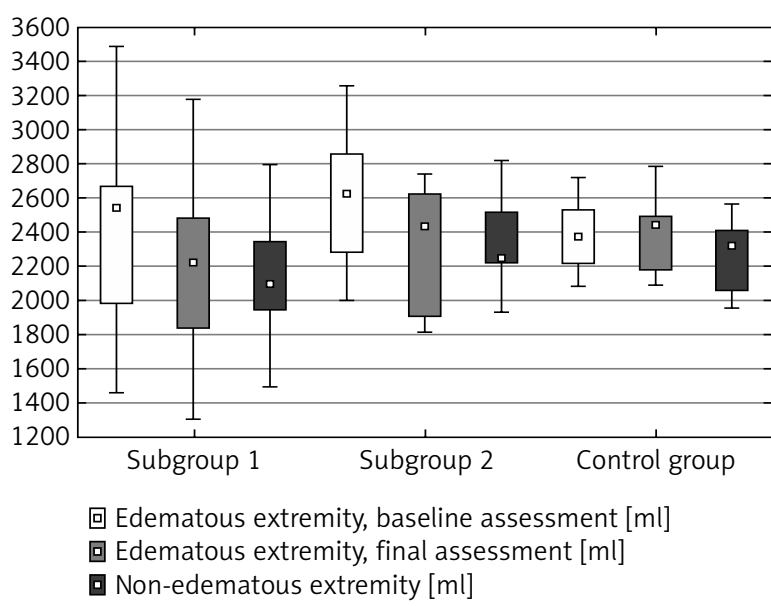

Fig. 2. Mean values [ml] obtained in 2 subgroups depending on the type of KT applications served as a result of KT applications. Figure 2 presents results referring to two sub-groups selected randomly based on the type of KT applications. A statistically significant reduction was found in both cases (cf. Table V).

\section{Discussion}

Lymph flow can be promoted e.g. by walking, arterial pulsation, lymphangiomotor function, muscle activity, physical exercise, massage or breathing, which are all recognized as causes of tissue deformation. Lymph formation and transport can be explained as a result of extension and compression of the initial lymphatics, determined by the deformation of tissues in which they are embedded. Passive exercise or cyclic compression have been shown to produce an increase in lymph flow rates in rabbit hind legs [7].

The observation suggests that all methods which deform the skin of the extremities may also improve lymph flow and hence can be successfully used for the therapy of peripheral lymphedema. At present, the mechanism is used by physical therapy comprising compression therapy, MLD and physical exercise.

A relatively new method of tissue deformation is KT, first developed in 1973 [3]. Kinesiology Taping has been increasingly used for lymphedema reduction even though its mechanism of action has not been sufficiently elucidated and there is no absolutely convincing evidence that KT is clinically beneficial. Kinesiology Taping is believed to alleviate pain or abnormal sensation, enhancing muscle function, removing lymph accumulating under the skin and improving the position of joints. Kinesiology Taping increases the space between the skin and muscle tissue, thus facilitating blood and lymph flow. Kinesiology Taping is better tolerated by patients and can be worn for 1-3 days - or longer. 
Tab. V. Significance of differences found in 2 subgroups depending on the type of KT applications

A) KT with anastomoses

\begin{tabular}{lccc}
\hline Subgroup 1 & $\begin{array}{c}p \\
\text { assessment 1 }[\mathrm{ml}]\end{array}$ & $\begin{array}{c}p \\
\text { assessment 2 }[\mathrm{ml}]\end{array}$ & $\begin{array}{c}p \\
\text { assessment 3 [ml] }\end{array}$ \\
\hline $\begin{array}{l}\text { assessment } 1[\mathrm{ml}] \\
p\end{array}$ & $\mathrm{X}$ & 0.06 & 0.01 \\
\hline $\mathrm{NE}[\mathrm{ml}]$ & 0.04 & 0.58 & 0.70 \\
\hline
\end{tabular}

B) KT without anastomoses

\begin{tabular}{lccc}
\hline Subgroup 2 & $\begin{array}{c}p \\
\text { assessment 1 }[\mathrm{ml}]\end{array}$ & $\begin{array}{c}p \\
\text { assessment 2 [ml] }\end{array}$ & $\begin{array}{c}p \\
\text { assessment 3 [ml] }\end{array}$ \\
\hline $\begin{array}{l}p \\
\text { assessment } 1[\mathrm{ml}]\end{array}$ & $\mathrm{X}$ & 0.01 & 0.01 \\
\hline$p$ & 0.01 & 0.01 & 0.70 \\
NE $[\mathrm{ml}]$ & &
\end{tabular}

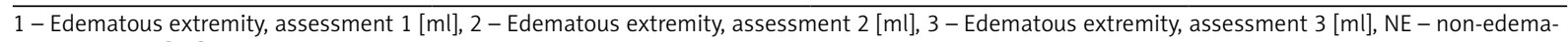
tous extremity $[\mathrm{ml}]$

Being waterproof, the tape does not need to be removed before washing.

Because of the progressive nature of lymphedema, the effects of treatment depend both on whether it is initiated early enough and whether the right method is adopted. Even early stages of lymphedema should not be overlooked since lymph circulation disorders adversely affect muscle function, fascia and skin tone, thus reducing patients' mobility [2].

Women post breast cancer treatment usually report reduced mobility and muscle weakness in the upper extremity on the operated side as well as pain, discomfort, subjective sensation of "tissue burst" and increased limb circumference, leading to the development of secondary lymphedema [8-10]. Disturbed lymph flow in mastectomy patients can manifest itself any time. It may emerge during the first postoperative days or have a latency period of up to 30 years [11]. Consequently, this group of patients should receive special care. The majority of women after breast cancer treatment scale down their daily physical activity, primarily due to fatigue, which is the most common symptom associated with cancer treatment $[12,13]$. Compromised physical activity, in turn, makes it impossible for lymph circulation to be improved by muscle pump activation, resulting in the development or exacerbation of secondary lymphedema. A vicious circle emerges. Reduced mobility, originally a consequence of disease treatment, decreases the activity of the muscle pump. Lymphedema occurs, further reducing the physical activity of patients and adversely affecting their daily functioning and quality of life, often leading to social isolation and mental disturbances [8, 14].

Therefore, it is vital to introduce edema prophylaxis and early physical therapy in patients. Depending on the site and type of application, KT can produce different effects. Applied in lymphologic disorders, KT improves lymph microcirculation. Regardless of the type of KT application (with or without anastomoses), a statistically significant reduction in circumferences was noted in the upper extremities on the operated side in the study group.

Lack of significant differences dependent on the type of KT application (with or without anastomoses) may stem from the discussion on the possible waste of lymph flow after armpit lymphadenectomy. The median sagittal lymphatic watershed boundary and the transverse lymphatic watershed boundary, divide the trunk into four quadrants. However the density of the anastomoses varies from individual to individual [15]. Besides, despite existing anatomical possibilities, collateral pathways will not form if the area is blocked by extensive scars. In this context, it is said that both the generation of new lymph vessels and the formation of lympho-lymphatic anastomoses play an important role [15].

The above result may thus suggest a successful use of KT in the initial symptoms of the lymphedema regardless of the lymphatic application used. The tape acts as a pump continually stimulating the lymph circulation on a $24 \mathrm{hr} /$ day basis. Next, there occurs lifting and folding of epidermis with the papillary layer of dermis. That, in result, leads to the increase in the blood flow capacity within the subpapillary vessel net and in deep skin vessels and multiplication of lymph transport from papilla lymph capillaries to blood vessels. Thanks to this process, more beneficial circumstances for regeneration within the morbid condition area develop. Finally, normalization of muscle tension appears followed by activation of blood and lymph flow and decrease in pain ailments and motility improvement [16].

Except for a few reports [2, 4, 17-20] in the literature, there are no well-conducted randomized, controlled studies with KT and breast cancer related lymphedema. More efficient treatment protocol is needed for clinical practice. 
In view of the above observations, it appears that KT applications might be beneficial in standard edemareducing physical therapy. Physical exercise is especially important during complete decongestive therapy, i.e. lymphatic drainage combined with bandaging. Limb bandaging, however, markedly reduces the possibility of leading an active life and performing a full spectrum of movements. In this light, replacing bandaging with KT applications seems a therapeutically reasonable solution. A study by Tsai et al. [6] confirms this possibility. The researchers demonstrated a significant reduction in the extent of lymphedema both in the group of patients receiving bandaging and in the group undergoing KT applications.

Benefits of this modification of CDT have also been demonstrated experimentally in rabbit studies. Kinesiology Taping combined with a 15-minute exercise program resulted in significant differences in lymph flow rates [7].

Physical exercise is of crucial importance for the elimination of edema, as the muscle pump promotes lymph flow. Insufficient physical activity may lead to inadequate outflow of lymph [17].

Kinesiology Taping thus opens up the way for a safe new therapeutic modality in the treatment of patients who have contraindications to other methods. It can be a good alternative for patients with bandaging problems (poor tolerance or contraindications resulting from coexisting conditions).

In a study by Tsai et al. [6], KT applications were better tolerated by patients than bandaging, mainly due to greater comfort and no problems with everyday activities. Kinesio Tex tape, similar in its properties to human skin, can be a simple and well-accepted method of edema management which, as a rule, is multi-phase, long and costly, and does not always bring entirely satisfactory results.

Major limitations of the present study were its relatively small study group, which increased the risk of randomness of results, and a short follow-up period. Future studies would be useful to investigate the extent of lymphedema reduction after KT applications in a larger group of patients. A bigger study group would increase the reliability of conclusions and lower the risk of errors. Furthermore, remote effects of the method should be monitored to evaluate long-term maintenance of efficacy.

\section{Conclusions}

1. Kinesiology Taping is an effective method of reduction in early-stage lymphedema of the upper extremity in women after breast cancer treatment.
2. Regardless of the type of KT applications, the edema was found to have decreased significantly.

3. There were no differences in the extent of edema reduction induced by different types of Kinesiology Taping.

\section{Disclosure}

Authors report no conflicts of interest.

\section{References}

1. Moseley AL, Carati CJ, Piller NB. A systematic review of common conservative therapies for arm lymphoedema secondary to breast cancer treatment. Ann Oncol 2007; 18: 639-646.

2. Białoszewski D. Przydatność kliniczna metody Kinesiology Taping w redukcji obrzęków kończyn dolnych u pacjentów leczonych metodą Ilizarowa - doniesienie wstępne. Ortopedia, Traumatologia, Rehabilitacja 2009; 1: 46-54.

3. Kenzo K, Walles J. Clinical Therapeutic Applications of the Kinesio Taping Method. $2^{\text {nd }}$ ed. Ken Ikai Co. Ltd., 2003.

4. Lipińska A, Śliwiński Z, Kiebzak W, et al. Wpływ aplikacji kinesiotapingu na obrzęk limfatyczny kończyny górnej kobiet po mastektomii. Fizjoterapia Polska 2007; 3: 258-269.

5. Put M. Taping jako metoda postępowania terapeutycznego. Fizjoterapia 2007; 15: 27-34.

6. Tsai H-J, Hung H-Ch, Yang J-L, et al. Could Kinesio tape replace the bandage in decongestive lymphatic therapy for breast-cancer-related lymphedema? A pilot study. Support Care Cancer 2009; 17: 1353-1360.

7. Shim JY, Lee HR, Lee DC. The use of elastic adhesive tape to promote lymphatic flow in the rabbit hind leg. Yonsei Med J 2003; 44: 10451052.

8. Smoot B, Wong J, Cooper B, et al. Upper extremity impairments in women with or without lymphedema following breast cancer treatment. J Cancer Surviv 2010; 4: 167-178.

9. Dawes D, Meterissian S, Goldberg M, et al. Impact of lymphoedema on arm function and health-related quality of life in women following breast cancer surgery. J Rehabil Med 2008; 40: 651-658.

10. Rietman JS. Long term treatment related upper limb morbidity and quality of life after sentinel lymph node biopsy for stage I or II breast cancer. Eur J Surg Oncol 2006; 32: 148-152.

11. Wójcik A. Metody obrazowania w diagnostyce obrzęku limfatycznego. Acta Balneologica 2007; 4: 223-233.

12. Winters-Stone KM, Bennett J, Nail L, et al. Strength, physical activity and age predict fatigue in older breast cancer survivors. Oncol Nurs Forum 2008; 35: 815-821.

13. Fialka-Moser V, Crevenna R, Korpan M, et al. Cancer Rehabilitation. Particularly with aspects on physical impairments. J Rehabil Med 2003; 35 : 153-162.

14. Chachaj A, Malyszczak K, Pyszel K, et al. Physical and psychological impairments of women with upper limb lymphedema following breast cancer treatment. Psychooncology 2010; 19: 299-305.

15. Földi M, Földi E. Textbook of Lymphology. Elsevier, Munich 2006.

16. Zajt-Kwiatkowska J, Rajkowska-Labon E, Skrobol W, et al. Kinesio taping metoda wspomagająca proces usprawniania fizjoterapeutycznego - wybrane aplikacje kliniczne. Nowiny Lekarskie 2005; 74: 190-194.

17. Senderek T, Breitenbach S, Hałas I. Kinesiotaping - nowe możliwości fizjoterapii kobiet w czasie ciąży. Fizjoterapia Polska 2005; 5: 266-271.

18. Szczegielniak J, Krajczy M, Bogacz K, et al. Kinesiotaping in physiotherapy after abdominal surgery. Fizjoterapia Polska 2007; 3: 299-307.

19. Szczegielniak J, Krajczy M, Bogacz K, et al. Kinesiotaping after thotacosurgeries. Fizjoterapia Polska 2007; 3: 344-350.

20. Szczegielniak J, Łuniewski J, Bogacz K, et al. The possibilities of using kinesio taping in patients after cardiac surgery. Fizjoterapia Polska 2007; 4: 456-471. 